\title{
The Unintended Consequences of Exile: The Brazilian and Chilean Cases in Comparative Perspective, $1964-1990^{1}$ \\ Cristian Doña-Reveco
}

\section{Introduction}

The right to asylum is a central theme in South American political identity. What originated as a way of protecting political leaders in the period of anarchy that followed the independence of these nations became, in the 1940s, a cornerstone of the inter-American political and legal systems. For the first century and a half of national independence in South American countries, the right to asylum was an elite status that guaranteed protection to political leaders deposed by political unrest or fearful of political retribution. These political elites usually sought asylum in neighboring countries: far enough from home for safety, but close enough to continue to participate in the political life of their country. In this sense, the cases of Sarmiento in the 1830s and 1840s and Haya de la Torre in the 1940s are quintessential examples of pre-1960s exile, asylum and the role of exile in Latin American political life. ${ }^{2}$

This elite idea of refuge violently ceased to exist in the Southern Cone of America in the $1960 \mathrm{~s}^{3}$ The rise of a new type of authoritarian and military government changed the characteristics of asylum and exile. This new form of political exile included not only elites but also myriad political activists and common citizens. Exile in the Southern Cone during the authoritarian-bureaucratic regimes of the 1960s, 1970s, and 1980s, followed several paths and those who suffered came from different walks of life. There were those directly expelled from their countries by their governments, those who sought asylum in an embassy, and those who left by their own means after realizing that they would not be able to find means of subsistence due to their political ideas. ${ }^{4}$ In terms of class and social position, they were state employees, academics, artists, and blue collars workers; they were either leaders in their political parties or sympathizers. They came from all regions of their countries. Once abroad, these exiles worked to build a life in their countries of reception, without abandoning the dream of returning as soon as possible to their countries of origin. Many of them also actively participated from abroad in opposition to the dictatorial governments in their countries. This process was not easy; they were hurt and defeated. Some of them had been tortured; their friends killed or disappeared, while they continuously asked themselves why they were still alive. 
These processes generated several unintended consequences. Mainly, exile served to coalesce a solidarity movement abroad that helped end dictatorships at home. In this article, however, I will examine two unintended consequences of Brazilian and Chilean exiles that have helped redefine the politics of the left and the center left in these countries in the last thirty years. In the case of Brazil I will deal with the realization of their own Latin American identity and in the case of Chile the renovation of the left which helped construct the Concertación de Partidos por la Democracia, the conglomerate of left and center parties that defeated Pinochet and stayed in power, democratically elected, for 20 years.

Using autobiographies and personal narratives of exiles, I examine these two unintended consequences of exile and the effects that it had in the countries of origin. In the following pages I first describe the current literature of exile in Brazil and Chile. I then locate the process of exile in the 1960s onwards as the result of a particular type of military government, which created massive human rights abuses. Then, through the voices of those who experienced it, I present the case of Brazil and the discovery of a Latin American identity followed by the case of Chile and the role of exile in the renovation of the left. I conclude this article by comparing these two processes, the Brazilian and the Chilean, and their effects on post-authoritarian governments. I state the need for further comparative analysis of exiles based on their multiple effects. Based on this analysis, I argue as well that it is time to re-evaluate the place of exile as a form of human rights abuse.

\section{The Literature of Exile}

The process of political exile in Brazil that began in 1964 is strongly connected to the Chilean exile that started in 1973. A large number of Brazilian exiles lived in Chile between 1964 and 1973. Some of them taught at Chilean universities (Fernando Henrique Cardoso, for example), or worked in high positions in the Chilean government (as Paulo Freire did). Many Brazilians had been involved in these political processes of change in their country of origin; a number of them participated as well in the revolutionary social movements that were changing Chile at the time. For Brazilian exiles in Chile, the military coup in Chile represented the need for a second exile. In turn, Chilean politicians and other citizens forced to flee Chile learned from Brazilian exiles what it meant to be an exile. ${ }^{5}$

Although there is a vast literature on the violations of human rights during the period of military dictatorships, this literature has centered mostly on the desaparecidos and on torture. Only recently has a systematic reference to exile emerged. As Loreto Rebolledo has argued in the case of Chile: 
...exile was a relevant theme that was part of the political discussion during the dictatorship, the demands to lift the ban on the return of the exiles was constantly presented by human rights lawyers, by the churches and La Vicaria de la Solidaridad. However once every exile was allowed to return to the country this topic became forgotten as a human rights violation. ${ }^{6}$

This still limited, albeit growing, historiography and scholarship of the process of exile in both countries can be traced to two main sources. The first source is in the arts. There is a vast literature and cinema that deals with exile, which originated very early in the process. Raúl Ruiz, for example, directed one of the first movies that dealt with this topic from the Chilean perspective in 1975 in France. The movie, titled Dialogue of Exiles, deals with the lives of Chilean exiles in France shortly after the coup of $1973 .{ }^{7}$ Filmed using mostly exiles who had never acted, the movie centers around discussions about everyday life, the idea of defeat, and the possibility of a short exile. Literature has shown a growing concern with the topic, particularly from authors who were exiles themselves. These authors have also dealt with the return to their countries after the end of the dictatorships. Examples include José Donoso and Carlos Cerda in Chile and Mario Benedetti in Uruguay, among many others. ${ }^{8}$

The second source is composed of rich life histories and memoirs from well-known politicians and common citizens. ${ }^{9}$ Most of these biographical accounts provide a perspective on individual suffering in exile, and while the authors locate themselves at the intersection of history and biography, in most cases they lack analysis of more macro impacts of exile. From a perspective of large-scale national histories and their historians, the process of exile and life experiences of exiles have been forgotten and hidden. Also, because the study of exile yields unpleasant truths about the past, it has not been well received in societies in the process of reconciliation. ${ }^{10}$ For many in the country of origin, exiles were thought of as a group that had it easier, since they were living in a different country and did not suffer everyday repression. ${ }^{11}$ However, as historical and sociological research has illustrated, exile is not an experience apart from the nation; instead, the personal and social experiences of exile and national oppression are inextricably linked. ${ }^{12}$ By contributing an everyday perspective, biographies and individual personal narratives and histories/stories of exile are key to understanding this period, since they humanize the fears, dangers, failures and successes of those who were compelled to leave.

Most recently, a new generation of scholarship on exile attempts to provide interdisciplinary, macro explanations of the process of exile using per- 
sonal narratives, governmental documents and archives, as well as other sources. ${ }^{13}$ In general terms this has been true for all of the Southern Cone. ${ }^{14}$ This second generation of studies has attempted to shed light on the macro impacts of the process. We are in the presence of works whose voice is that of the collective and not only the individual memory, as well as works that explain the role of exile in economic, social, and political change in the countries of origin. ${ }^{15}$ Still, much essential work is still lacking: the process of recuperating the memory of exile, its impacts on countries of origin and reception, the process of return, and above all its location within the human rights abuses of the Southern Cone dictatorships of the second half of the Twentieth century, as well as comparative analyses that deal with the multiple realities of exiles and the multiple South American nations that have suffered from this experience. ${ }^{16}$ These analyses are of utmost importance to the construction of future societies in both countries and to the reconstruction of nations that have suffered political and social traumas.

\section{Bureaucratic-Authoritarian Regimes and Exiles}

The United States' role in the political processes that led to the military coups in South America is well documented. ${ }^{17}$ In general terms, the objective of the United States in these countries was to block leftist parties from the government in order to avoid a second Cuba, and thus to oppose the advance of global socialism. In particular, the participation of the United States took the form of three major actions: financing development projects through the Alliance for Progress, funding of center and right wing political parties as a way of preventing the left from gaining and maintaining the presidency, and training military officers who became the leaders of military coups and insurrections. ${ }^{18}$ Military support through educational exchange between military schools and equipment sales, for example, had been permanent since the nineteenth-century but increased from the 1950s onwards with the creation of the School of the Americas. ${ }^{19}$ Although the impact of this program was not the same in every Latin American country, its objective was to train officers from the armies of these countries in counter-insurgency, antiterrorism, and anticommunist ideologies. This indoctrination had deep consequences for both Chile and Brazil since several of the School's alumni went on to head the secret police of the military governments and other intelligence organizations of a repressive nature. The School of the Americas was much more successful in preventing the rise of social and military leftist revolutions than the Alliance for Progress, which consisted of economic aid, tied aid in most cases, for the development of rural areas of Latin America. ${ }^{20}$ 
The dictatorships that rose to power in the Southern Cone, beginning with the Brazilian in 1964, were able to succeed because of a particular number of objective conditions. First, they emerged in the more industrialized Latin American societies. Second, they were characterized by an institutionalized military rule. Third, these dictatorships had a "historical project" through which they attempted to transform their societies as a whole, in their social, economic, cultural, and political characteristics. ${ }^{21}$ This explains their duration and the reason that, unlike previous military regimes such as Chile in 1924, militaries did not transfer power back to civilians soon after the coup. Fourth, they were supported by a group of trans-nationalized technocrats who followed an ideology that linked national security and economic development. Finally, the rise of these regimes was in part a product of the internationalizing of U.S. security doctrines through foreign police and military assistance since the $1950 \mathrm{~s}^{22}$

These dictatorships are what Guillermo O'Donell and others named Bureaucratic- Authoritarian Regimes. ${ }^{23}$ These authors use a systemic or structural approach to understand these processes of political change and the reason behind the high levels of violence. For O’Donnell and Garretón, the military governments in power in the Southern Cone felt that they had to fulfill a specific historical project: to free their countries from Marxism and moral decadence. Because of this, the members of the ruling juntas were always comparing themselves with the founding fathers and liberators of these nations. ${ }^{24}$ These new dictatorships were qualitatively different from those that had come before. They put into action a military structure that sought to change the political culture and the system of government, thus creating what O'Donnell termed a bureaucraticauthoritarian regime. ${ }^{25}$

This concept is intended to characterize a state that has the following characteristics. First, individuals who have completed successful careers in highly bureaucratized and complex organizations, such as the army or big companies, usually occupy the higher echelons of government. Second, these are systems of political exclusion; they attempt to limit access to the state to the popular sector and its political allies. Third, these are also systems of economic exclusion; they reduce and postpone to an unspecified future the economic aspirations of the popular classes. Fourth, these regimes attempt to break the political requirements of civil society. To achieve this, they reduce social questions and public policies to technical problems that have to be solved through arrangements in the higher echelons of state organizations. Finally, these regimes correspond to a stage of profound transformations in the processes of accumulation in their societies, a stage that takes part in consolidation of a peripheral industrial capitalism. ${ }^{26}$ 
The rise of these regimes is a response to fast processes of mass mobilization and political consciousness among the popular classes. This is perceived by other sectors of the population as a threat to the continuation of defined socio-economic structures, which eventually ends in the dominant sector imposing this regime using the armed forces as the moral reserve of societies.

Besides being regimes of torture, disappearance and murder, these dictatorships were also responsible for the largest politically and economically induced exile process in the history of the continent. The estimates of this exile are as high as half a million Uruguayans (from a total of 2.9 million at mid-year 1980), between 400,000 and 600,000 Chileans (of a population of around 11 million in 1980), between 500,000 and 2 million Argentineans (of a population of 28 million in 1980) and from 5,000 to 15,000 Brazilians, all of whom had to leave their country during military rule. ${ }^{27} \mathrm{~A}$ significant number of these exiles never returned to their countries of origin. ${ }^{28}$

The physical expulsion of those against the regimes was a central component of the politics of fear and destruction of the opposition. It allowed the regimes to present those who were against the dictatorships as traitors to their nation and to their own ideals. The propaganda of the dictatorships published accounts in which they presented the exiles as people living the golden life in Europe or other countries, or told how they had escaped prison while other members of their parties were tortured and left behind. ${ }^{29}$ An example of this, in the case of Brazil, is the regime's slogan: Brasil: Ame-o on Deixe-o! (Brazil, love it or leave it!). In the words of Santos and Rolland:

This slogan efficiently characterizes the years of dictatorship in Brazil ... Exile is necessarily an instrumental mechanism, used to varying degrees by authoritarian governments. The real and supposed opponents are declared illegitimate, who must at best be silenced, or they will end up in jail ... in the best case. ${ }^{30}$

The particular characteristics of these new dictatorships are behind the high levels of violence they used to produce fear in their population. Exile was one of the means used to continue producing fear. As we will see below, the results were not necessarily those expected by the military in power.

\section{The Brazilian case: The discovery of a Latin American identity}

The military coup that deposed João Goulart in 1964 was the preface to what would happen in most of South America in the following years. ${ }^{31}$ Even the 
rationale behind the need for a military coup, the beginnings of the coup, and the ensuing dictatorship were similar. On the one hand, a progressive government that followed either socialist, leftist, or liberation theology ideas; and on the other, the conservative owners of business and haciendas and right wing parties supported by the United States.

The Brazilian coup, according to Rabêlo \& Rabêlo, originated in a political and social crisis that was seen by right wing politicians and the military as a threat that could end in a socialist or communist revolutionary process. ${ }^{32}$ Goulart tried to nationalize the electrical companies and created a state-owned enterprise to regulate nuclear power, a recent development in Brazil. This was not well received by the owners of the service companies, who in return began supporting a movement that lead to the military coup. According to Cardoso: "[W] hat happened in April 1964 was not just a coup, it was a profound clash in Brazilian society. The elite classes felt the experiment with democracy had failed ... The ensuing 'reorganization' did not destroy merely people, but entire segments of society." 33

The repression in Brazil at the beginning of the military government was not as hard as it would soon be in the rest of the Southern Cone countries. During the first days following the coup, only those with strong political participation were asked to present themselves at police stations and detained, and only those that had a relevant position in the government asked for diplomatic asylum. Torture also was not a common trend among those imprisoned. ${ }^{34}$ As mentioned before, this was different from what would happen in Chile, where a large number of people asked for diplomatic asylum in the first days of the coup, partly due to the observed experience of Brazil.

The low level of repression would change after 1968. Two key things happened in that year. First, groups of students, mostly coming from the Brazilian elites, began revolutionary movements to destabilize the military governments. These groups attempted two strategies to gain public favor: bank robberies to access monetary resources that would allow them to undertake other activities, and kidnapping of foreign ambassadors according to their relevance in trade relations between Brazil and the country of origin. Although this strategy was not successful, and after a few months the guerrilla movements

had been completely disarticulated, it succeeded in exchanging the captives for political prisoners, which led to both an increase in the number of exiles and a change in the characteristics of the exiles. 
Second, in part as a response to these urban guerrilla movements, was the passing of the Institutional Act Number 5, which marked the triumph of the "hard-liners" within the dictatorship, and the systematization of murders, detention and torture of those opposed to the regime. ${ }^{35}$ If those who had left the country in the early days of the coup were center and center-left elites, including João Goulart himself, those that left after 1968 were mainly younger Marxist activists and were not directly related to the older political or intellectual elite. ${ }^{36}$ In the words of Sznajder and Roniger, "[W] hereas the goal of those in the first wave [1964] was to redress the end of democracy and defend reformism, for those in the '1968 wave,' the central goal was revolution."37

The first two notable themes that emerge from the personal accounts and memoirs of the exiles are questioning of the defeat and certainty of a nearterm return. ${ }^{38}$ This will be the same in the Chilean case. The first group of exiles continuously questioned and debated the reasons behind the defeat. This question, which was mainly a private matter and not a public activity, resonated through conversations between former politicians and other supporters of Goulart's government. ${ }^{39}$ Beatriz Bandeira Ryff remembers that as she was leaving Brazil in route to exile in Yugoslavia:

Small groups joined in interminable conversations about politics, the recent and current occurrences whose analysis took a long time. These discussions were heated, passionate, and filled with remembrances and anecdotes, but always very peaceful. ${ }^{40}$

Ana Montenegro reflects that exiles carry a dual baggage, one that is political and emotional at the same time; it is a conversation also with the exile's ghosts and the continuous attempt to do a cold analysis of the factors that lead to this situation. ${ }^{41}$ Even after a decade, in 1974, when all of the Southern Cone but Argentina was under the rule of dictatorships, Montenegro remembers meeting with friends for dinner and asking themselves how and why Latin America did not learn the Brazilian lesson.

The certainty of near-term return, that condition which kept many exiles living literally with their suitcases packed, was based on a memory or experience of previous military governments. ${ }^{42}$ According to this memory, the 1964 military governments would be short-lived and benign; as had happened before, exiles assumed that after a couple of years the military dictatorship would end and all exiles would be able to return to their countries. Cardoso, in his memoirs, recollects the following discussion: "My friend Celso Furtado leaned across the table trying to comfort him. 'Don't worry', Celso said. 'The dictatorship will last 
two years at most.' Wainer looked up at Celso, indignant. 'There is no way the military would hold to power that long!' he declared." 43 The attributes of the bureaucratic-authoritarian regime defined above, particularly its clear and specific ideology, allowed the military to remain in power for the following 21 years.

A second important situation that arises from the narratives and biographies is the discovery of a shared Latin American origin among (at least) those Brazilians exiled in Chile, Bolivia and Mexico. ${ }^{44}$ Until the 1980s Brazil had a dual relationship with Latin America. On the one hand it belonged and participated in all the hemispheric international organizations. On the other it had an active but distant bilateralism with other Latin American nations. ${ }^{45}$ Its past experience as an empire, its use of a distinct language and its own hegemonic ambitions separated Brazil from the rest of the continent. This relationship was mutual; the Latin American countries did not generally consider Brazil one of their own. ${ }^{46}$

José Maria Rabêlo, a Brazilian who lived as an exile in Bolivia, Chile, and France with his wife and seven children, remembers that it was soon after his arrival in Bolivia that he first 'discovered' Hispanic America. He argues that Brazilians did not originally think of themselves as Latin Americans. For them, Brazil was superior to the rest of the continent, "even with a colonial perspective, as if Brazil was that different from them". ${ }^{47}$ He mentions that in Bolivia he came to realize that the university traditions were older than in Brazil, that the culture was more complex, and that it was closely tied to the presence of respected indigenous values and the struggles for resistance. These characteristics of Bolivia, he argues, were seen in Brazil as a caricature, something 'folkloric', transmitted by the colonizers. Later, during his exile in Chile, this Latin Americanism was reinforced by the presence of exiles from the entire continent, who "gave us an idea of the realities of each of their countries" and concludes by stating that: "These discoveries produced a special feeling in us with regards to the cultural, political, economic and social complexity of the other side of Latin America. When we left Brazil we thought that we were going to teach; soon we realized that we had much to learn."48

Fernando Henrique Cardoso makes a similar argument. He argues that while he did not leave Brazil for intellectual reasons, he intellectually discovered Latin America in Chile through contact with scholars from all of Latin America. It is this connection with other Latin American scholars that influences his work with Enzo Faletto and the publication of Dependency and Development in Latin America, arguably one of the most relevant social science theories produced in Latin America. ${ }^{49}$ 


\section{Doña-Reveco}

The discovery of this Latin American identity was not only at the level of intellectuals but also at the level of shared political and social struggles. In this sense Montenegro states that "most of the exiles who arrived in Mexico and other Latin American countries would find themselves for the first time among 'Latin-American brothers' ... these exiles would discover America, five centuries after it was discovered". ${ }^{50}$ The similarity between the political processes experienced by Brazil and the countries of the Southern Cone amazed the Brazilian exiles and led them to recognize that they were part of Latin America as well. In the same vein Darcy Ribeiro, quoted by Pinheiro Machado recalls:

The exile was a necessary process for us to comprehend that we belong to a general category of peoples with a common destiny. Since we arose as peoples within the same circumstances and we have a parallel destiny ... [The process of colonization] is a process of the Americas in general, which suffered a strong, hard occupation, having as a result the most homogenous area of the Earth. We have a unity of past and future destiny. ${ }^{51}$

Finally Montenegro concludes that:

The process of exile allowed many of us to find the reasons behind our current difficulties through a new and better understanding of the other countries in our continent, within their cultures, their troubles, their contemporary and past struggles, and the differences between our identities and theirs ... 52

Chile, for the fugitives of the Brazilian dictatorship, was a symbol of freedom, an "El Dorado" for Brazilian exiles or "the Mecca of the World's Left". 53 The political changes that Chile was going through attracted their interest and attention. It was the place to be to learn what the other America, the Hispanic America was about. This was the case of Márcio Moreira Alves, a young prominent opponent to the dictatorship, known for having denounced torture and written a book about torture in Brazil. He escaped to Chile where he was convinced by a former minister of João Goulart to stay in the country to learn about Latin America. Moreira Alves recalls that this former Minister told him:

"You know nothing about Latin America. If you stay a year or so you will learn about Latin America, and then you can go to Europe” ... So I [Moreira Alves] did what I needed to do, was convinced about the importance of Hispanic America, and I stayed in Chile a year and a half. ${ }^{54}$ 
For many exiles Chile was the example that revolution could be done in a democratic setting. After September 11 1973, however, that would change. The brutal repression that followed affected both Chileans and foreigners, since the latter were considered Marxist infiltrators. Among them were many Brazilian exiles. ${ }^{55}$ For a second or third time the Brazilians had to leave, although this time was the worst. ${ }^{56}$ Their dreams of a successful revolution were shattered, they were detained by soldiers in concentration camps, they sought asylum in embassies, they were taken out of the country with the help of diplomats and employees of international organizations, and finally for some they arrived to a new exile mostly in Europe for the remaining eight or ten years. Their native country, however, did not help them. The Brazilian ambassador to Chile, Câmara Canto, was nicknamed the fifth member of the Junta, due to the aid he provided to the four members of the Chilean Junta in securing loans and in detaining Brazilian exiles residing in Chile. As the night of the dictatorship settled in Chile, many Chileans were beginning to suffer the same destiny as the Brazilians they had hosted; they would have to leave the country for a good part of the seventeen years of the Chilean dictatorship. ${ }^{57}$

\section{The Chilean Case: The Road to a Renewed Left}

Although there was some sense that a military coup was being prepared and would happen soon, the Chilean government under Allende was never prepared to defend itself. Allende, in his last speech on the morning of September 11 1973, mentioned that he would not surrender, but never called for an armed defense of the government. On the one hand, it seemed there was hope that the strong constitutional doctrine of the Chilean armed forces would stop a military coup. On the other, the coup was extremely well orchestrated especially by the Navy where detentions and torture of leftist sailors began as early as 1972, presenting no opportunity for possible counterattacks by ill-armed factory workers. On a similar note, the strong verticality of command of the Chilean armed forces prevented any possibility of opposition from within. ${ }^{58}$

As in the case of Brazil, the Chilean coup was a reaction by local military and right-wing parties to the possibility of the country following a socialist revolutionary process. Unlike the Brazilian case where the US sent a navy and marine detachment to aid the Brazilian military in case of need, the Chilean coup was not directly supported by the United States. Regardless of this, the Chilean political process that began in 1958 with the election of Alessandri (1958-1934), continued during Frei's government (1964-1970), and ended with the September 11, 1973 coup was directly and indirectly influenced by the United States. During this fifteen-year period, Chile was successively governed by 
a right-wing coalition with Alessandri; a center coalition with Frei; and a leftwing coalition with Allende. Each coalition had at the time close to 33 percent of the votes; hence, this period is now known as the period of the "three thirds" and was marked by increasing political polarization of Chilean society, and profound political, social, and economic changes in the nation.

Allende's government expanded the social reforms begun during the previous two governments. During his rule, he completed the nationalization of the copper mines, until then in the hands of US companies, increased the scope of the land-reform program and directly or indirectly nationalized several industries. This process enraged the higher classes and right-wing parties, and also complicated relationships with some of the professional and middle classes, as well as with their main political preference, the Christian Democrat party. At the same time the United States, fearing the establishment of a new Cuba on the American continent, began a destabilization policy on the day that Allende was elected that included denial of loans to fix and replace machinery used in copper production, financing of right wing terrorism, and initiation of contacts with conservative groups and pro-right military to create a situation that would lead to a military takeover. ${ }^{59}$ These external influences, along with internal strikes and sabotages by right wing groups, influenced social unrest and macroeconomic crisis that produced the conditions for a military coup. ${ }^{60}$

Unlike the case of Brazil, the repression of the supporters of Allende's government began immediately and was more severe. The great majority of tortures, summary killings and disappearances happened between 1973 and 1978. The estimates for the first two years are between 20,000 to 30,000 exiles; 80,000 political prisoners; and deaths ranging from a conservative calculation of 3,000 to a high estimate of $30,000 .{ }^{61}$ The leadership of the political parties that formed the governing coalition under Allende (namely the Socialist, Communist and other smaller parties) were completely disarticulated and their members were either killed, disappeared or exiled. Only six months after the coup, in March of 1974 , the military government declared, “...the armed forces do not set timetables for their management of the government, because the task of rebuilding the country morally, institutionally, and economically requires prolonged and profound actions". 62 According to Wright and Oñate, this rebuilding involved the "extirpation of Marxism and its doctrine of class struggle and their replacement with the values of conservative Catholicism, class harmony, and Chilean nationalism." 63

The Chilean exile followed several paths abroad. During the first month following the coup a significant number of Chileans, composed mostly of the political elite of the government that had survived the coup and avoided the first 
waves of detentions, asked for diplomatic asylum in many embassies. They were joined there by mid-level political activists and by foreigners, as we have seen in the case of Brazilians. In the years that followed the coup, many other Chileans that had been detained in concentration camps were expelled from the country. ${ }^{64}$ Norambuena estimates that close to 76 percent of the exiles left the country with their families; 52 percent left Chile between 1973 and 1976; 16.3 percent between 1977 and 1980; and close to 10 percent between 1980 and 1984. ${ }^{65}$ This last group was comprised also of economic exiles that, due to their political beliefs, had no opportunity to get a job in Chile. Norambuena also stresses that psychological problems were common among the exiles, with higher than normal proportions of alcoholism and depression. ${ }^{66}$ There are at least 12 documented cases of exiles committing suicide while living abroad, a phenomenon that is also present in the Brazilian case. ${ }^{67}$

As in the Brazilian case, the renovation of the Chilean left began in the embassies. This change came with the debate over the reasons for the defeat. Allende formed his coalition, the Unidad Popular (UP), from two main parties, the Socialist and the Communist, and a set of smaller groups and parties such as the MAPU (Popular Unitary Action Movement), a faction of the Radical Party, and the Christian Left, among others. Within the left but somewhat outside of the UP was an insurrectional movement, the MIR or Revolutionary Left Movement. By 1973 Allende's coalition was completely divided in terms of how to confront the de facto blockade of the United States, the right, and the Christian Democrats, and how to continue and expand the socialist revolution. Two main visions clashed within the coalition. On the one side, the Communist Party wanted to continue a democratic revolution even at the expense of negotiating with the Christian Democrats. The Socialists and the MIR on the other wanted a more radical revolution, even arming themselves as a defense against a coup that they anticipated. At the time of the coup, the MIR decided to stay in Chile and militarily confront the dictatorship while the leaderships of the socialists and the communists, as well as the other smaller parties, sought refuge in embassies. ${ }^{68}$

Discussions of who should be blamed (United States' imperialism, communists or socialists) for the defeat of the revolutionary process led to selfquestioning about the state of the Left in the world. ${ }^{69}$ These discussions were bitter and led to continuous cross-accusations about who carried the most blame. The communists argued that it was the socialists' and MIR's fault because of their lack of understanding of the Chilean process. The socialists argued that it was the communists' fault and their lack of revolutionary zeal but more generally that "the left had not been sufficiently Leninist". ${ }^{70}$ The MIR argued that the fault lay with the idea of developed reformist politics at a time when conditions 
were ripe for the revolution. ${ }^{71}$ In the words of a Brazilian exiled in Chile:

The truth is that the Chilean experience kept going around my head. The amount of mistakes made by the left, and particularly by the far left, made it intolerable to reconcile with a foolish radicalism. I was ready to write a book on the Chilean coup opposing the theses defended by the left. Without exceptions, all the politicians that fought in Chile, socialists, communists, or from other leftist parties, argue that the factor responsible for the fall of the government was the United States' imperialism. Almost none of them would mention the significant contribution that the left made with its own mistakes, its arrogance, its naïveté, and its own stupidity. ${ }^{72}$

These traumatic life experiences, the fall of Allende, the coup and its share of murder, imprisonment and exile, were the "catalysts for ideological and role transformation". 73 The experience of exile became a political renovation in many cases. There were numerous multiparty conferences to attempt to explain the defeat and to decide the best way to end the military government. ${ }^{74}$ There were differences, however, among those who belonged to the political apparatchik and other thinkers and scholars from the left. The party loyalists continued participating in politics as, "virtually an extension of party politics conducted in another fashion ... [which] seemed to have had little effect on their political ideologies." "75 For the intellectuals and scholars from the left, on the other hand:

[E]xile allowed them to reflect a good deal on past position and to be engaged in networks of international debate that lent distance and perspective to the Allende period, to internal party politics, and to socialism as theory and praxis. ${ }^{76}$

Puryear and Wright share this point. Puryear argues that the possibility of meeting with other intellectuals in Europe, the development of networks, think-tanks such as the Institute for the New Chile and the journal Chile-America were key in the process of re-constructing and re-thinking the role of the left in a democratic Chile. ${ }^{77}$ Wright argues that "[E]xposure to politics in super-developed social democracies, the decline of statism within the Western European Left, and (for some) living in socialist countries all had profound effects on the exiles."78 This created a profound gap between the former allies (communists and socialists) and within the parties themselves. Shortly after the death and disappearance of their leadership in the country, both parties began to move away from their pre-coup positions and to develop new strategies. ${ }^{79}$ While an important group of socialists became more moderate and switched to the center, the 
Communist Party supported a military insurrection against the dictatorship, an effort that was defeated, thereby reducing the influence of this party in Chilean politics. Other former communists, having the experience of living in countries of the communist bloc, were disappointed by the lack of freedom within these countries. An important number of these leaders left the Communist Party and moved to the Socialist Party presenting themselves more as Euro-communists than as Soviet communists. As Hite argues by citing Antonio Leal:

Between my contact with the PCI (Italian Communist Party) and my link with the PCCH (Chilean Communist Party) youth ... it meant that already by the late 1970 s the majority of us on the Central Committee, at least the Executive Committee of the Jota, understood that the world had changed radically, that the socialist bloc had serious defects, that there couldn't be democracy without human rights. ${ }^{80}$

The Socialist Party had always been a party of divisions; it had a "loosely structured party organization". 81 This process was only accentuated once abroad, where the many factions split into a continuum in which Marxist socialism and Western European social democracy were the extremes. The latter moved to the center of the political spectrum and joined Radicals and Christian Democrats to establish the Concertación de Partidos por la Democracia, a political conglomerate that had the role of negotiating the democratic transition and was in power until 2010. Many of the former exiles that belonged to the elites have had cabinet positions in the four governments of this coalition (two of the last five presidents have been former exiles, as is the current general secretary of the Organization of American States). This coalition has also had the role of creating means to learn the truth of what happened during the dictatorship, and created in 1990 the Oficina Nacional del Retorno (National Office for the Return of Exiles) whose objective was to properly bring back those who had left the country. 82

Not all exiles agreed with this movement to the center, or at least with the reasons behind the renovation. Some felt that the renovation was something done by elites, not taking into consideration the sentiments of middle level party members or even those who worked for Allende and the government outside of Santiago. Alejandro was a member of the Socialist party in the far south of Chile and currently is an exile living in Chicago. At the time of the coup he was in charge of the state-run tourism office in Punta Arenas. He was detained, tortured, sent to prison in a concentration camp at Dawson Island, relegated to Chiloé, and in 1975 received a change of his sentence to exile in the United States. In an interview he told me: 
The people that went to Europe brought [to Chile] new ideas, or changed their radical ideas for ... well reality also changed them a lot, but they became renovated, then it does not exist anymore, I dare to say that they are not leftist anymore, I mean it is a huge frustration, not only for me, but for my entire generation. ${ }^{83}$

\section{Unintended Consequences and Human Rights}

The consequences of the military dictatorships for these countries were enormous. Beyond the number of deaths, torture victims, disappearances, and exiles, they produced massive changes to the relations between the state, civil society, and political parties; to the relations between the economy and society; and to the culture of the nation. ${ }^{84}$ As I have shown here, exile also meant, for Brazilians, the discovery of their belonging to Latin America and, for Chileans, the renovation of the left.

The discovery of a Latin American identity can be exemplified by the changes in Brazil's foreign policy in the last 25 years. Historically, Brazil has consistently defined itself as a regional power. Its position, with its most important cities looking towards the Atlantic, defined the characteristics of its foreign relations. While the foreign policy would not change until the return of the former exiles to power in the late 1980s and early 1990s, it was during the dictatorship years that Brazilian intellectuals from the left began to feel part of Latin America. According to Bethell this was "often directly a consequence of years spent in exile during the Brazilian military dictatorship in Uruguay (until the coup there in 1973), Chile (until the coup against Allende, also in 1973), Mexico and Venezuela". 85 After the return to democracy in 1985, Brazil pushed for a stronger integration with Latin America and in particular with South America. The political decision to form MERCOSUR, leaving behind decades of animosities with Argentina is one of these changes. ${ }^{86}$

These processes of integration became even more relevant during the governments of Cardoso, himself an exile in Chile in 1965, and Lula. ${ }^{87}$ Cardoso hosted a meeting of South American presidents in 2000, and under Lula's leadership the South American Community of Nations was formed in 2004. Cardoso defined the 2000 meeting as "a reaffirmation of South America's own identity as a region". ${ }^{88}$ Brazil no longer has its back to the other Latin American countries, but has turned towards them. This was mostly the result of the exiles who left Brazil to discover Latin America in the late 1960s.

The Chilean return to democracy in the late 1990s has been considered one of the most peaceful and successful democratic transitions in recent history. This transition did not occur without strong compromises and fears. 89 The left, 
in particular the Socialist Party, had to learn through the death of hundreds of its members that their intransigent undemocratic position during Allende's government did not make it possible to regain power and win election in a country such as Chile that prides itself as being historically the most democratic of the region. ${ }^{90}$ This meant a turn to a more pragmatic approach to politics. ${ }^{91}$ It also meant giving concessions to other parties in order to remain in power. Finally, the struggle against dictatorship and life in the Eastern Bloc countries meant a "...reevaluation of democracy and the refutation of authoritarian rule" which ruled out the possibility of a dictatorship of the proletariat, which had been one of the objectives of the 1970-1973 Socialist Party. ${ }^{92}$ This rejection of revolution, according to Puryear, and its exchange for democratic reform "meant seeking the creation of democratic national culture rather than an emancipatory project geared toward a particular social sector. ${ }^{93}$

The benefits of these unintended consequences, the increased participation in Latin America by Brazil and the successful democratic transition of Chile, do not negate the fact that the dictatorships, which ruled these countries, were machines of terror. The exile of the 1960s and 1970s intended to remove and eliminate generations that were against the project of the military regimes, a project that defined a particular economic and political order. In this sense it belongs to the same level of human rights abuses and corresponds to the same logic as the torture and the killings, as Rollemberg argues. ${ }^{94}$ It has not, however, been considered in the truth commissions that have been developed in these countries to investigate the crimes of the dictatorships. So far, in the case of Brazil, the truth commission set by the Archdiocese of São Paulo, and not by the government, deals with torture and disappearances and not with exile. ${ }^{95}$

The new Comissão Nacional da Verdade established by the government of Dilma Rousseff and approved on September 21 2011, while dealing with torture, murders and disappearances both inside and outside of Brazil, does not incorporate exile as a human rights abuse. ${ }^{96}$ In the case of Chile, although there was a policy to help return Chilean exiles by giving them tax breaks, helping them finance housing, and allowing the recognition of education from other countries, the process of exile has not been present in any of the truth commissions set by the democratic governments since $1990 .{ }^{97}$

A possible explanation of the dismissal of exile, accepted by many who stayed in the countries during the dictatorships, is that exile is not a matter of human rights; after all, they are still alive. They did not suffer the repression, did not see the disappeared or tortured, and did not suffer the fears of the state of siege. Except for those expelled from the country, most exiles left Chile with 
their passports and on regularly scheduled flights; this was used to ground the propaganda against exiles as people who left because they wanted to leave. While many suffered economic and social hardships, Pinochet's government used the higher levels of income and education achieved by some to discredit the plights of the exiles. ${ }^{98}$ These arguments were based on the propaganda by both dictatorships that exiles were traitors to their nations who were living a "golden exile" or "jet set" lifestyle in Europe funded by their political parties. ${ }^{99}$ As the personal narratives cited in this paper attest for both Chilean and Brazilian cases, however, it is possible to observe the deep disruption that the experience of exile had for both individuals and families.

This is also present in the literature that refers explicitly to the process of return. They had a hard return to a new country, and the recognition that for many they were simply away, as if they were on holiday and not affected by the dictatorship. As Pablo Yankelevich argues for the case of Argentina,

[E]veryone who returned during the first few years after the end of the dictatorship felt the weight of that emblematic and condemning phrase, 'it was because of something' with which parts of the society badly hid the complaisant silence with the criminal policies of the Argentinean Armed forces."100

Almost thirty years have passed since the end of the last dictatorship of the Southern Cone. It is time to re-evaluate the place of exile as a human rights abuse. It is also time to encourage the development of more research on the effects of exile, not only at the individual level, but also at the macro level. I have presented here only two possible, albeit critical, non-anticipated consequences of the processes of exile: the "discovery" of Latin America by Brazilians and the reform and renovation of the Chilean left. There are multiple others in the individual narratives: tales of heroism and of sorrow, of conquer and defeat, and above all of remembrance of those who died.

There is also a growing and extremely interesting literature on the gender worlds of Southern Cone exile. ${ }^{101}$ It tells stories of women that were abandoned by their partners, or who were relegated to secondary positions in the solidarity movements abroad after being leaders in their countries. We do not, however, have extensive research on the impact of the exiles in their countries of reception, and even less in their countries of origin. Close to three decades later, we do not know how many children of exiles went back to the countries of their parents and remained there. We have only started to scratch the surface of this topic, and a thorough analysis of these processes is a key component in the dis- 
cussions of memory, reconciliation, and the re-constructions of these nations, since those who were exiled and never returned, the children who stayed in the countries of asylum, and the foreign partners who came back will always be part of these nations. In the words of Mónica Palma Mora:

Exile, once it begins, never ends. The returnee, even glad of return, continues living in two worlds. The nostalgia that wanted to heal by returning to their native land, their people, and their dreams becomes nostalgia for those that were left behind. That which was good of the asylum revives always the pain of distance. The returnee continues being an exile and always will be. 102 


\section{NOTES}

1 The author would like to thank Breanne Grace and Dr. Peter Beattie and two anonymous reviewers at Left History for their comments and contributions on earlier versions of this article. I would also like to thank Matt Penniman for his editorial revisions. Any remaining errors are my own.

2 Mario Sznajder and Luis Roniger, The Politics of Exile in Latin America (New York: Cambridge University Press, 2009). Domingo Faustino Sarmiento was an Argentinean writer, educator, politician, and president of Argentina (1868-1874). Between 1831 and 1855 he spent several periods as an exile in Chile during Juan Manuel de Rosas' dictatorship in Argentina. From there he attacked the dictatorship as director of the influential newspaper El Mercurio de Valparaiso. Victor Raúl Haya de la Torre was a Peruvian politician and founder of the APRA (American Popular Revolutionary Alliance) Party, a leftist anti-imperialist party that advocated Latin American integration, socialism and recognition of the indigenous origins of Latin American nations. He was exiled several times in his life. In 1948, after a failed revolt in Peru, he sought asylum in the Colombian Embassy where he stayed for the next five years. The international judicial case that ensued reinforced the role of regional custom in Latin American international law, in particular customs of diplomatic and territorial asylum.

3 There are two basic definitions of the Southern Cone. The first includes Argentina, Chile, and Uruguay, while the second adds Paraguay and Brazil to this group of countries. For analytical purposes I will use the second definition in this article.

${ }^{4}$ Hugo Cancino, "Exilio chileno e historiografía," Sociedad y discurso, Año 2, No. 4, (Otoño, 2003), http://vbn.aau.dk/files/62991009/SyD4_cancino.pdf (accessed August 2, 2012) and Carmen Norambuena, "Exilio y retorno. Chile 1973-1994," in Memoria para un nuevo siglo: Chile, miradas a la segunda mitad del siglo XX, ed. Mario Garcés and Myriam Olguín Tenorio (Santiago: LOM Ediciones, 2000), 173-187.

5 While Chilean communists suffered internal and external exile in the late 1940s when the Law of Defense of Democracy was passed, there was no real understanding of exile as a mass movement of population. The number of exiles between 1948 and 1958 was small compared to those that left the country after 1973.

6 Loreto Rebolledo, "Mujeres Exiliadas: Con Chile en la Memoria," Cyber Humanitatis, 19 (2001): Footnote 7 http://web.uchile.cl/publicaciones/cyber/19 /rebolledo.html\#7v (accessed October 26, 2012). See also Loreto Rebolledo, 
Memorias del desarraigo: testimonios de exilio y retorno de hombres y mujeres de Chile, (Santiago de Chile: Catalonia, 2006), 15-16.

${ }^{7}$ Raúl Ruiz, Diálogo de exiliados, (Francia: Videostar, 1975).

8 Amy Kaminsky, After Exile: Writing the Latin American Diaspora, (Minneapolis: University of Minnesota Press, 1999); Fernando Alegría, Chilean Writers in Exile: Eight Short Novels, (Trumansburg, N.Y.: Crossing Press, 1982); Ignacio LópezCalvo, Written in Exile: Chilean Fiction from 1973-present, (New York: Routledge, 2001); José Donoso, $n$ de al lado, (Santiago de Chile: Aguilar Chilena de Ediciones, 1996); Carlos Cerda, Tres novelas (Morir en Berlin, Sombras que caminan y Una casa vacia), (Santiago de Chile: Alfaguara, 2003); Mario Benedetti, Primavera con una esquina rota, (México: Editorial Nueva Imagen, 1982).

${ }^{9}$ Fernando Henrique Cardoso, The Accidental President of Brazil: A Memoir, (New York: Public Affairs, 2007), 77-103; Cristina Pinheiro Machado, Os exilados: 5 mil brasileiros á espera da anistia, (São Paulo: Editora Alfa-Omega, 1979); José Maria Rabêlo and Thereza Rabêlo, Diáspora: os longos caminhos do exílio, (São Paulo, SP, Brasil: Geracáo Editorial, 2001). Denise Rollemberg, Exílio: entre raízes e radares, (Rio de Janeiro: Editora Record, 1999); Thomas C. Wright, "Legacy of Dictatorship: Works on the Chilean Diaspora," Latin American Research Review, 30 no. 3 (1995): 198; Thomas C. Wright and Rody Oñate, Flight from Chile: Voices of Exile, (Albuquerque: University of New Mexico Press, 1998); Ariel Dorfman, Heading South, Looking North: A Bilingual Journey, (New York: Farrar, Straus, and Giroux, 1998); Yolanda Avena Pires, Exílio: testemunho de vida, (São Paulo, SP: Casa Amarela, 2001); Evandro Afonso do Nascimento, Lembrancas do exílio Chile, Panamá, República Democrática Alemã e Costa Rica, (Uberlndia: O Autor, 2008); Antonio Ribeiro Romanelli, 1964, minhas histórias do cárcere e do exílio, (Belo Horizonte, MG: Mazza Edições, 1994) among many others.

10 Cancino, "Exílio Chileno e Historiografía" and Rollemberg, "Nômades, sedentários e metamorphoses," in O Golpe Militar E A Ditadura: 40 Anos Depois (19642004), Daniel Aarão Reis, Marcelo Ridenti and Rodrigo Patto Sá Motta, (Bauru, SP: EDUSC, 2004).

11 Rebolledo.

12 Norambuena, "Exilio y Retorno"; Ana Vásquez-Bronfman and Ana María Araújo, La maldición de Ulises: Repercusiones Psicoló Gicas Del Exilio, (Santiago, Chile: Editorial Sudamericana, 1990).

13 Sznajder and Roniger, The Politics of Exile in Latin America; Marita Eastmond, The Dilemmas of Exile: Chilean refugees in the USA, (Göteborg, Sweden: Acta Universitatis Gothoburgensis, 1997); James N. Green, We Cannot Remain Silent: Opposition to the Brazilian Military Dictatorship in the United States, (Durham, NC: Duke University Press, 2010); Vásquez-Bronfman and Araújo, La maldición de Ulises; Julie Shayne, They Used to Call us Witches: Chilean Exiles, Culture, and Feminism, (Lanham: Lexington Books, 2009); Luis Roniger, James N. Green, and 
Pablo Yankelevich (eds), Exile and The Politics of Exclusion in the Americas, (Eastbourne: Sussex Academic Press, 2012) and several doctoral dissertations. 14 Erasmo Sáenz Carrete, El Exilio Latinoamericano En Francia: 1964-1979, (Ciudad de México: Potrerillos Editores, 1995); Pablo Yankelevich and María Luisa Tarres, En México, entre exilios: una experiencia de sudamericanos, (México, D.F.: Secretaría de Relaciones Exteriores, 1998); Pablo Yankelevich and Silvina Jensen, Exilios: destinos y experiencias bajo la dictadura militar. (Buenos Aires: Libros del Zorzal, 2007); Silvia Dutrénit, El Uruguay del exilio: gente, circunstancias, escenarios, (Montevideo, Uruguay: Trilce, 2006).

15 Rebolledo; Rollemberg, "Nômades, sedentários e metamorphoses"; Pedro Cavalcanti, Celso Uchoa, and Jovelino Ramos, Memórias do exílio, Brasil 1964-19??: obra colectiva, (Lisboa: Editorial Arcádia, 1976); Association Participa (Lille), Femmes chiliennes en exil: récits de vie, (Lille: Geai bleu ed., 2008), Eastmond, The Dilemmas of Exile and Sznajderand Roniger, "Political Exile in Latin America".

16 With regards to comparative essays, there is one that compares the Chilean and Uruguayan exile. Cfr. Mario Sznajder and Luis Roniger, "Exile Communities and their Differential Institutional Dynamics: A Comparative Analysis of the Chilean and Uruguayan Political Diasporas," Revista de Ciencia Política 27 no. 1 (2007): 43-66.

17 Arthur Preston Whitaker, The United States and the Southern Cone: Argentina, Chile, and Uruguay, (Cambridge, Mass.: Harvard University Press, 1976); Peter Kornbluh, The Pinochet file: A Declassified Dossier on Atrocity and Accountability, (New York: New Press, 2004); Green, We cannot remain silent.

18 Martha Knisely Huggins, Political Policing: The United States and Latin America, (Durham: Duke University Press, 1998).

19 Cf. Lesley Gill, The School of the Americas: Military Training and Political Violence in the Americas, (Durham: Duke University Press, 2004).

20 Jeffrey F. Taffet, Foreign Aid as Foreign Policy: The Alliance for Progress in Latin America, (New York: Routledge, 2007).

21 Manuel A. Garretón, The Chilean Political Process, (Boston: Unwin Hyman, 1989), 50.

22 Huggins, 117-118.

23 Guillermo O'Donnell, Modernization and Bureaucratic-Authoritarianism: Studies in South American Politics, (Berkeley: Institute of International Studies, University of California, 1979); Juan J. Linz and Alfred C. Stepan, The Breakdown of Democratic Regimes, (Baltimore: Johns Hopkins University Press, 1978); Juan J. Linz and Alfred C. Stepan, Problems of Democratic Transition and Consolidation: Southern Europe, South America, and Post-Communist Europe, (Baltimore: Johns Hopkins University Press, 1996); Garretón, The Chilean Political Process; Arturo Valenzuela, The 
Breakdown of Democratic Regimes: Chile, (Baltimore: John Hopkins University Press, 1991). As a general analysis of the democratic breakdowns that lead to bureaucratic-authoritarian regimes, the Linz-Stepan school (of which Valenzuela was also part) argues that the democratic breakdown is a result of failures in the power relationship in the party system. For these authors, political systems remain in equilibrium by having a strong center party that is able to answer the systemic requirements of the extremes through processes of negotiation. Once that center is no longer capable of maintaining equilibrium and political participation polarizes to the left and right of the party system, a democratic breakdown occurs.

24 O'Donnell, Modernization and Bureaucratic-Authoritarianism, 85-91 and Garretón, The Chilean Political Process, 46.

25 Huggins, 117.

26 Guillermo O'Donnell, Counterpoints: Selected essays on Authoritarianism and Democratization, (Notre Dame, Ind, University of Notre Dame Press, 1999), 35.

27 In my analysis, the relatively small number of Brazilians is a consequence of a more elite-driven exile. Alternately, since the dictatorship in Brazil was the first to rise, its military did not have a defined policy of exile at the regime's inception, and there was no previous knowledge of how severe the repression would be. For the other countries, the Brazilian experience taught exiles-to-be that repression would be hard and that leaving was a better option to save lives. This is demonstrated by the number of people who asked for asylum in embassies in the first month of the dictatorship. The total estimates of populations are drawn from CELADE Demographic Bulletin No. 69. (Santiago: ECLAC, 2002). The sources of the estimates of exiles are Mario Sznadjer and Luis Roniger, "Political Exile in Latin America," in Roniger et al Exile and The Politics of Exclusion in the Americas (13-35) for Uruguay; Wright and Oñate, Flight from Chile for Chile; Silvina Jesen and Pablo Yankelevich, Una aproximación cuantitativa para el estudio del exilio político argentino en México y Cataluña (1974-1983), (El Colegio de México: Centro de Estudios Demográficos y de Desarrollo Urbano, 2007): 399-442 for Argentina; and Sznajder and Roniger, The Politics of Exile in Latin America, 196 for Brazil.

28 Sofía Correa, Consuelo Figueroa and Alfredo Jocelyn Holt, Historia del siglo XX chileno: balance paradojal, (Santiago: Ed. Sudamericana Chilena, 2001); Thomas Skidmore and Peter H. Smith, Modern Latin America, (New York: Oxford University Press, 2005); Rabêlo and Rabêlo, Diáspora: os longos caminhos do exilio; José del Pozo Artigas, Exiliados, emigrados y retornados: chilenos en America y Europa 1973 - 2004, (Santiago de Chile: Ril Editores, 2006).

29 Rebolledo. 
30 Idelette Fonseca dos Santos and Denis Rolland, Le Brésil des gouvernements militaires et l'exil, 1964-1985: violence politique, exil et accueil des Brésiliens en France, témoignages et documents, (Paris: L'Harmattan, 2008): 8 [my translation].

31 Santos and Rolland, 8.

32 Rabêlo and Rabêlo, 52.

33 Cardoso, 83.

34 This does not imply that there was no torture or assassinations during this period. According to Sznajder and Roniger more than 6,500 people were prosecuted between 1969 and 1974. In the same period there were an estimated 206 executions and at least 151 disappeared. They argue that between 1968 and 1973 there were 2,800 political prisoners in one prison in Brazil, most of who underwent torture (Sznajder and Roniger, 198).

35 Celso Castro, The Military and Politics in Brazil: 1964-2000, (Oxford: Centre for Brazilian Studies, University of Oxford: 2000).

36 Thomas E. Skidmore, Brazil: Five Centuries of Change, (New York: Oxford University Press, 1999); Rollemberg, 283.

37 Sznajder and Roniger, 200.

38 Beatriz Bandeira Ryff, A resistencia: Anotações do exílio em Belgrado, (Rio de Janeiro: Walter Duarte, 1990); Ana Montenegro, Tempo de exiźlio, (Aracaju, Sergipe: Edições Novos Rumos, 1988); Cardoso, The Accidental President of Brazil, Pinheiro Machado, Os exilados; Rabêlo and Rabêlo, Diáspora: os longos caminhos do exiilio.

39 Pablo Yankelevich, Represión y destierro itinerarios del exilio argentino, (La Plata: Ediciones Al Margen, 2004).

40 Bandeira Ryff, 14 [my translation].

41 Montenegro.

42 Santos and Denis Rolland.

43 Cardoso, 87.

44 Denise Rollemberg, "The Brazilian Exile Experience: Remaking Identities," Latin American Perspectives n. 34 (2007): 81-105; Rabêlo and Rabêlo.

45 Helio Jaguaribe, "El Brasil y la América Latina,” Foro Internacional 15 no. 4 (1975): 607-637; Luiz Alberto Moniz Bandeira, "Brasil, Estados Unidos y los procesos de integración regional. La lógica de los pragmatismos," Nueva Sociedad, n. 186 (2003): 143.

46 Leslie Bethell, "Brazil and 'Latin America'," Journal of Latin American Studies 42 n. 3 (2012): 457-485.

47 Rabêlo and Rabêlo, 26.

48 Rabêlo and Rabêlo, 26, 27. 
49 Carina Alejandra Black, Fernando Henrique Cardoso: Intellectual Evolution From Exile to Presidency, (Thesis (Ph. D.) University of Nevada, Reno, 1997), 98.

50 Montenegro Tempo de exílio, 32 [my translation].

51 Pinheiro Machado, 37.

52 Montenegro, 38 [my translation].

53 Pinheiro Machado, 95; Rabêlo and Rabêlo.

54 James N. Green, "Brazilian Exiles in the United States: A Human Right Discourse," in Roniger et al Exile and The Politics of Exclusion in the Americas: 163182, 168.

55 Pinheiro Machado; Rabêlo and Rabêlo, 137.

56 It was a third time for those who had originally exiled themselves to Argentina, Uruguay, or Bolivia before going to Chile.

57 Pinheiro Machado, 104; Rabêlo and Rabêlo, 159; Rollemberg, 107.

58 Correa, Figueroa and Jocelyn-Holt, Historia del siglo XX chileno, 274-276.

59 Peter Kornbluh, The Pinochet File: A Declassified Dossier on Atrocity and Accountability, (New York: New Press: 2003), 12-28.

60 Correa et al, 265-275.

61 Correa, et al, 287.

62 Wright and Oñate, 5.

63 Wright and Oñate, 5.

64 Norambuena, 177.

65 Norambuena, 177-178.

66 See also Vásquez-Bronfman and Araújo, 23.

67 Rabêlo and Rabêlo, 81; Rollemberg, 286.

68 Ricardo Yocelevzky, Chile, partidos politicos, democracia y dictadura 1970-1990, (Santiago, Chile: Fondo de Cultura Económica, 2002); Norma Stoltz Chinchilla and William Bollinger, "Introduction: Theoretical Issues of the Chilean Experience," Latin American Perspectives, 1 no. 2 (1974): 3-8; and Kyle Steenland, “The Coup in Chile," Latin American Perspectives, 1 no. 2 (1974): 9-29.

69 Wright and Oñate, 53.

70 Jeffrey Puryear, Thinking Politics: Intellectuals and Democracy in Chile, 1973-1988, (Baltimore: Johns Hopkins University Press, 1994): 61.

71 Stoltz Chinchilla and Bollinger, 5.

72 Ferreira Gullar, Rabo de foguete: os anos de exílio, (Rio de Janeiro, RJ: Editora Revan, 1998), 226 [my translation.]

73 Katherine Hite, When The Romance Ended: Leaders of the Chilean Left, 1968-1998, (New York: Columbia University Press, 2000), xvi. 
74 Federico Guillermo Gil, Ricardo Lagos Escobar, and Henry A. Landsberger, Chile at the Turning Point: Lessons of the Socialist Years, 1970-1973. (Philadelphia: Institute for the Study of Human Issues, 1979), 4.

75 Hite, 128.

76 Hite, 128.

77 Puryear, 63.

78 Thomas C. Wright, "Legacy of Dictatorship: Works on the Chilean Diaspora," Latin American Research Review, 30 no. 3 (1995): 198; 204.

${ }^{79}$ Kenneth M. Roberts, Deepening Democracy? The Modern Left and Social Movements in Chile and Peru, (Stanford, Calif: Stanford University Press, 1998), 83.

${ }^{80}$ Hite, 139. The Jota is the youth section of the Chilean Communist Party. It is named after the Spanish sounds of the first letter in its acronym JJCC

(Juventudes Comunistas - Communist Youth).

81 Roberts, 48.

82 Wright and Rody Oñate; Norambuena; Correa, Figueroa and Jocelyn-Holt.

83 Interview with Alejandro Ferrer, Chicago January of 2011.

84 Daniel Aarão Reis, Marcelo Ridenti and Rodrigo Patto Sá Motta, O golpe e a ditadura militar quarenta anos depois (1964 - 2004), (Bauru, SP: EDUSC, 2004); Garretón, The Chilean Political Process; and Manuel A. Garreton, La Faz sumergida del iceberg: estudios sobre la transformación cultural, (Santiago: LOM, 1993), 128.

85 Bethell, 482.

86 According to Moniz Bandeira, Cardoso argued in 2001 that "MERCOSUR is more than a market; is, to Brazil, its destiny"; Moniz Bandeira, "Brasil, Estados Unidos y los procesos de integración regional", 150.

87 Cardoso, 221.

88 Moniz Bandeira, 149.

89 Patricio Silva, "Collective Memories, Fears and Consensus: The Political

Psychology of the Chilean Democratic Transition," in Societies of Fear: The Legacy of Civil War, Violence and Terror in Latin America, Kees Koonings and Dirk Kruijt, (London: Zed Books, 1999), 171-196.

90 Carlos Altamirano, Dialéctica de una derrota, (Mexico: Siglo Veintiuno Editores, 1979). An interesting counterpoint to this was published by the President of the Chilean Senate and member of the Socialist Party Camilo Escalona in 2010 in a letter entitled Altamirano o el Desprecio a lo Popular. Availabe at http:/ / www.socialismo-chileno.org/PS/index.php?option=com_contentandtask $=$ viewandid $=1486$ andItemid $=48$ (Accessed August 1, 2012). 
91 Eduardo Ortiz, "Chilean Socialism and Transition," Economic and Political Weekly, 28 no. 40, (1993): 2124-2129.

92 Patricio, Silva, Social Democracy, Neoliberalism and Ideological Change in the Chilean Socialist Movement, 1973-1992, paper presented at the XVII International Congress of the Latin American Studies Association, Los Angeles, California, September 24-27, 1992, available at https://lasa.international.pitt.edu/members/congresspapers/lasa1992/files/SilvaPatricio.pdf, (Accessed August 1, 2012).

93 Puryear, 61-62.

94 Rollemberg, 281, 290.

95 cf. Joan Dassin, and Jaime Wright, Torture in Brazil: A Shocking Report on the Pervasive use of Torture by Brazilian Military Governments, 1964-1979, (Austin, Tex: Institute of Latin American Studies, University of Texas, 1998). While this book is an improtant source to learn about human rights abuses during the Brazilian dictatorship, it makes no reference to exiles being a human rights abuse that the Archiodese of São Paulo should investigate.

96 The law that creates the Commission states in its Art. 3, number II "promover o esclarecimento circunstanciado dos casos de torturas, mortes, desaparecimentos forçados, ocultação de cadáveres e sua autoria, ainda que ocorridos no exterior;" available at http://www.cnv.gov.br/ (Accessed on October 2, 2012). 97 These were The National Commission for Truth and Reconciliation Report of 1991 (the Rettig Report) which dealt with political assassinations, and The National Commission on Political Imprisonment and Torture Report of 2004 (the Valech Report), which obviously dealt with torture.

98 Rebolledo.

99 Rebolledo, 16; Wright \& Oñate, 149; and Thomas C. Wright and Rody Oñate, "Chilean Political Exile," in Exile and the politics of exclusion in the Americas, Luis Roniger, James Naylor Green, and Pablo Yankelevich (eds), (Eastbourne: Sussex Academic Press, 2012): 145-62, 146.

100 Yankelevich, Represian y destierro itinerarios del exilio argentino, 10 [my translation]. 101 Shayne, They Used to Call us Witches; Association Participa (Lille), Femmes Chiliennes en Exil; Albertina Costa, Memórias das mulheres do exílio: obra coletiva, (Rio de Janeiro: Paz e Terra, 1980).

102 Mónica Palma Mora, "Destierro y Encuentro. Aproximaciones al exilio latinoamericano en México 1954-1980," Amérique Latine Histoire et Mémoire, No. 7 (2003 - Migrations Etats-Unis Mexique terre d'accueit), http://alhim.revues.org/document363.html (accesed August 2, 2008), 18. 